\title{
Die Nag-Hammadi-Schriften in der Literatur- und Theologiegeschichte des frühen Christentums
}

\author{
Hrsg. v. Jens Schröter u. Konrad Schwarz
}

Die Nag-Hammadi-Schriften in der Literatur- und Theologiegeschichte des frühen Christentums Herausgegeben von JENS SCHRÖTER und KONRAD SCHWARZ

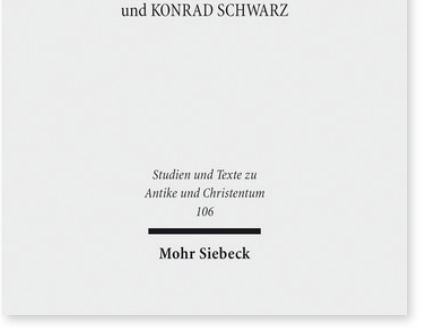

2017. IX, 316 Seiten. STAC 106

ISBN 978-3-16-155521-3

DOI 10.1628/978-3-16-155521-3

eBook PDF 104,00

ISBN 978-3-16-155365-3

fadengeheftete Broschur 104,00 €
Der vorliegende Band versammelt die Beiträge einer Tagung, die 2015 an der Humboldt-Universität zu Berlin stattfand, dem Jahr, in dem sich der Fund der Nag-Hammadi-Codices zum 70. Mal jährte. Die Perspektive des Bandes ist darauf gerichtet, die Nag-Hammadi-Schriften im Kontext der Literatur- und Theologiegeschichte des frühen Christentums zu interpretieren. Damit wird ein bislang nur wenig beachteter Aspekt in den Vordergrund gestellt. War die Diskussion über die Nag-HammadiSchriften bislang häufig darauf gerichtet, deren Verhältnis zur antiken Gnosis bzw. zu den Schriften des Neuen Testaments zu untersuchen, so wird hier ein anderer Ansatz verfolgt. Die Schriften werden entsprechend ihren literarischen Gattungen (etwa: Apokalypsen, theologische und philosophische Traktate oder Evangelien) in den Blick genommen. In Beiträgen international renommierter Forscher wird untersucht, in welcher Weise die Nag-Hammadi-Schriften diese Gattungen realisieren und wie sich ihre Stellung innerhalb der Literatur und Theologie des antiken Christentums beschreiben lässt.

Inhaltsübersicht

Jens Schröter: Einleitung - Christoph Markschies: Offene Fragen zur historischen und literaturgeschichtlichen Einordnung der Nag-Hammadi-Schriften - John D. Turner: The Reception and Transformation of Philosophical Literary Genres in the Nag Hammadi Writings

\section{Apokalypsen in den Nag-Hammadi-Codices}

Gregor Wurst: Apokalypsen in den Nag-Hammadi-Codices - Jaan Lahe: Die Apokalypse des Adam als ein Werk am Rande der Theologie- und Literaturgeschichte des frühen Christentums - Dylan M. Burns: Is the Apocalypse of Paul a Valentinian Apocalypse? Pseudepigraphy and Group Definition in NHC V,2

\section{Mythologische Traktate in den Nag-Hammadi-Codices}

Nicola Denzey Lewis: Mythological Treatises in the Nag Hammadi Codices - Ursula Ulrike Kaiser: »Und sie wurde unter ihren Händen ein Baum« (HA, NHC II,4 p. 89,26f.). Die Hypostase der Archonten und die antike Mythologie - Karen L. King: The Apocryphon of John: Genre and Christian Re-Making of the World

\section{Liturgische Texte in den Nag-Hammadi-Codices}

Hugo Lundhaug: Prayer in the Nag Hammadi Codices - Antti Marjanen: Baptism in the Holy Book of the Great Invisible Spirit (NHC III,2 and IV,2)

\section{Evangelien in den Nag-Hammadi-Codices}

Simon Gathercole: The Nag Hammadi Gospels - Paul-Hubert Poirier: From 1897 to 2015: Some Aspects of the Research on the Gospel according to Thomas - Katrine Brix: The Gospel of Truth - Judith Hartenstein: Die Weisheit Jesu Christi (SJC)

\section{Theologische und philosophische Traktate in den Nag-Hammadi-Codices}

Einar Thomassen: Theological and Philosophical Treatises in the Nag Hammadi Codices - Uwe-Karsten Plisch: Zostrianus, der philosophisch orientierte Sethianismus und das Gebet des Seth

Jens Schröter Geboren 1961; 1992 Promotion; 1996 Habilitation; Professur für Exegese und Theologie des Neuen Testaments sowie die antiken christlichen Apokryphen an der Theologischen Fakultät der Humboldt-Universität zu Berlin. https://orcid.org/0000-0001-7878-2709

Konrad Schwarz Geboren 1983; 2003-11 Studium der Ev. Theologie in Berlin und Pietermaritzburg (Südafrika); 2011 Erstes Theologisches Examen; seit 2013 wissenschaftlicher Mitarbeiter an der Theologischen Fakultät der Humboldt-Universität zu Berlin; 2018 Promotion.

Jetzt bestellen:

https://mohrsiebeck.com/buch/die-nag-hammadi-schriften-in-der-literatur-und-theologiegeschichte-des-fruehenchristentums-9783161555213?no_cache=1

order@mohrsiebeck.com

Telefon: +49 (0)7071-923-17

Telefax: $+49(0) 7071-51104$ 